\title{
Rare earth elements' waste management for smartphones' touch screens by system dynamics modelling
}

\author{
Aziz Kemal Konyalıoğlu ( $\nabla$ konyalioglua@itu.edu.tr ) \\ 2443-5063 \\ Ilke Bereketli \\ Galatasaray Üniversitesi: Galatasaray Universitesi
}

Istanbul Technical University - Ayazaga Campus: Istanbul Teknik Universitesi https://orcid.org/0000-0002-

\section{Research Article}

Keywords: system dynamics, smartphones, rare earth elements, closed loop supply chain, waste management, simulation

Posted Date: May 14th, 2021

DOI: https://doi.org/10.21203/rs.3.rs-458455/v1

License: (c) (i) This work is licensed under a Creative Commons Attribution 4.0 International License. Read Full License 


\section{Abstract}

Developments in smartphones' technology affect mobile phone use rates in the world. Increasing use of internet in the last 10 years parallelly force people to use smartphones not only in the work but also in their private lives. This high amount of consumption brings together the problem of excessive amount of waste, and also raises environmental concerns about how to treat them in the end-of-life phase of the smartphones. It is known that a classic smartphone, which is composed of battery, electronics, case part and touch screen, can be dissembled and recycled even though less than $20 \%$ of smartphones are going through reusing and recycling in the world. One of the problematic parts of the smartphones' waste management is the touch screen. Rare earth elements used in touch screens are scarce sources, which are mainly silver, gold, palladium, indium, gadolinium, terbium, yttrium and lanthanum, and these elements cannot be easily substituted. In case they are not reused or recycled, they will be lost forever. In this paper, it is aimed to propose a system dynamics model for rare earth elements' reuse and recycling in smartphones' touch screens by a closed loop supply chain view. The design of the system dynamics modelling is operated and simulated by Anylogic and Stella simulation softwares which give perspective to observe how to better manage rare earth elements' closed loop supply chain in order to increase the rate of reuse and recycling by considering important and relative factors of waste management system.

\section{Introduction}

Development in network and working technologies, together with consumerism make smartphones widely used all around the world. (Geyer and Blass, 2010). Although a mobile phone lifetime is stated as approximately 10 years, the average usage period of a typical mobile phone is 3 years and 2 years in developing countries and in developed countries respectively, which implies that the duration reaching the end-of-use for smartphones are far shorter than expected (Huang et al., 2009, Soo and Doolan, 2014). Parallel to that, mobile phone waste has been rising up because of dramatically increasing rate of production and consumption (Sarath et al., 2015). It is stated that $75 \%$ of mobile phone users generally throw their phones away to the garbage without any waste treatment method, and only less than $20 \%$ of smartphones are reused and recycled yearly (URL1).

Figure 1 shows the waste management process of smartphones. Smartphones include many recyclable materials, although most of them is not reused or recycled actually. Moreover, a typical mobile phone is made up of different types of materials including plastics, glass, ceramic, ferrous and non-ferrous metals, rare and precious elements which are also included in other electronic devices.

It is mostly known that rare elements are crucial for every electronic device, for some parts of the smartphones, especially their touch screens (Jowitt et al., 2018). In touch screens of smartphones, palladium, gold, silver, lanthanum, terbium etc. are used (URL2). They are categorized under rare earth elements and considered as the very important ones compared to other earth elements. Regarding this fact, it is very problematic that approximately only $1 \%$ of rare earth elements are recycled.

In this study, it is aimed to propose and design a closed loop supply chain model by a system dynamics approach in order to increase the reusing and recycling ratios of rare earth elements in touch screens of 
smartphones considering different rare earth elements, such as Gold, Silver, Yttrium, Lanthanum, Indium, Terbium and finally Palladium. An efficient and effective waste management system's behavior of rare earth elements in smartphones can be observed by the relative factors changes in system dynamics, which is suitable for modelling. The originality of the study comes from the fact that, although these rare earth elements in smartphones can be recycled in a proper way and they are becoming a scarce resource, there is not any study in the literature focusing on that problem and combining the system dynamics approach and rare earth elements' waste management in smartphones' touch screens.

\section{Literature Review}

\subsection{System Dynamics in Waste Management}

In the literature, there are studies applying system dynamics approach in the waste management area, WEEE and other types waste processing, especially in the last 10 years (Cai et al., 2016). Dhanshyam and Stivastava (2021) applied system dynamics approach in order to observe the policy efficiency of plastic waste management in India and tried to reach the most effective roadmap for proposing to policymakers. Another study in solid waste management by a system dynamics approach is illustrated by Lu et al. (2021) considering the interaction between the generation of municipal solid waste, greenhouse gas emission, economic and environmental impact and life cycle assessment of these types of waste per capita in China versus Gross Domestic Product (GDP). In municipal solid waste management area, Pinha and Sagava (2020) assessed a system dynamic modelling for promoting the awareness of managers in order to reduce costs by a view of zero budget balancing. At the same year, Liu et al. (2020) used system dynamics modelling as an environmental assessment modelling for demolition and construction waste in Guangzhou and analyzed three main impacts of these types of waste consisting of environmental, social and economic impacts. Phonphoton and Pharino (2019) evaluated flooding effects on municipal solid waste management by a system dynamics approach and analyzed waste collection and transfer processes in vulnerable areas in Thailand. Lee et al. (2018) used a system dynamics modelling in different scenarios for investigating policies of food waste in Hong Kong and considered interrelated factors affecting food waste management policy's efficiency in order to suggest the details for how to improve the current policy.

Sukholthaman and Sharp (2016) evaluated the effects of source separation on solid municipal waste in Thailand by a view of system dynamics and envisaged the source separation dynamic effects by a scenario analysis in a 120-month periods. In Waste of Electric and Electronic Equipment (WEEE) area, Ardi and Leisten (2016) assessed a system dynamics modelling for informal recycling sector affecting WEEE management system dynamics as a secondary market. Additionally, Dace et al. (2014) analyzed eco-design policies of packaging waste management by the aid of system dynamics methodology in order to observe if policies are effective on recovery rates and material efficiency in Latvia. Ciplak and Barton (2012) evaluated healthcare waste generated by healthcare sector including hospitals, clinics and medical centres in Istanbul by system dynamics with the aim of supporting a decision system, planning and simulating the waste amount until 2035 and concluded that a high amount (77\%) of healthcare waste would be possible with modern treatment technologies. In the area of household waste management, Inghels and Dullaert (2011) used system dynamics modelling for the aim of analyzing household waste management policy underlying 
the dynamic factors affecting GDP and collection rates in Flanders. The study of Pinha and Sagava also considers financial aspects in Brasil. Hao et al. (2008) proposed a decision tool for construction waste in order to better manage demolition waste by a system dynamics approach and to understand relative factors affecting and causing dynamic waste problems.

\subsection{Waste Management of Smartphones}

In smartphones area, there also exist some studies but there is not any study including system dynamics for evaluating rare earth elements waste management in smartphones. Firstly, In China, He et al. (2020) performed a life cycle cost analysis for high-tech minerals in mobile phone waste and while analyzing, they divided into two groups including simple phones and smartphones for extracting various high-tech minerals. Gu et al. (2019) analyzed recovering materials of mobile phone waste and the latest technological developments by reviewing articles and identified material recovery processes of mobile phone waste. Yao et al. (2018) evaluated environmental effects of smartphones waste management in China by using system dynamics methodology including life cycle assessment of smartphones. On the other hand, Sinha et al. (2018) studied and identified product systems including material flows of smartphones and also collection systems and policies of mobile phone waste by the aid of system dynamics modelling. Xu et al. (2016) compared China's policies and technology for not only waste management system of smartphones but also other electric and electronic waste management systems with other developing countries. Thavalingam and Karusena (2016) evaluated the process of identification, public contribution in Sri Lanka and legislation of mobile phone waste and also analyzed if people are aware of mobile phone waste management importance. Yla-Mella et al. (2015) investigated the perception in Finland towards reuse and recycling of smartphones' waste, included in electronic waste and the advertisement and publicity effects on public awareness, which is aimed to increase public awareness.

In China, Yin et al. (2014) studied on consumers' behaviour towards mobile phone waste recycling with a questionnaire and surveying, and formed a metric of consumer behaviour about mobile phone. The crucial result of this study is that most consumers are willing to pay $0-5 \%$ of recycling cost and the affecting factors are education, region and monthly income. Jha et al. (2013) tried to investigate lithium and cobalt recoveries in the smartphones' batteries and studied on dissolution lithium and cobalt mechanism. Another study in Czech Republic done by Polak and Drapalova (2012) estimated smartphones end-of-life generation, which assigns the targets for mobile phone waste collection, and they are only reached if the target is more realistic. Ongondo and Williams (2011) surveyed the incentives for smartphones waste collection and concluded that incentives highly support take-back operations of smartphones effectively and create awareness of collection mobile phone waste. Another survey study has been done by Nnorom et al. (2008) investigating the willingness of Nigerian citizens to recycle mobile phone waste and to pay more for green smartphones.

\section{Methodology And Modelling}

System dynamics and causal loop diagrams are very useful tools to see the system behavior and affecting factors which change system behavior. In this study, we aim to observe how the reuse and recycling rate 
change in time according to different collection approaches. Therefore, these two methods fit well with our proposed methodology.

\subsection{Methodology Description}

System dynamics can be defined as the methodology to understand the complex system's behavior by the time. (Forrester, 1993). The system, as a whole, includes stocks, feedback mechanisms, negative or positive relationships, dynamics variables in order to understand the relation between interrelated variables and how a change of a variable in the complex system affects on the other variable in the system. In order to start analyzing the system, firstly it is essential to understand if the existing system is suitable for being a system or not as the system dynamics methodology is based on cause-effect relationship between variables (Forrester, 1961). As Forrester (1994) stated, system dynamics has some conceptual parts, which are factors of the system, feedbacks and causalities, stocks, dynamic variables and flows.

Richardson (2020) defined the basic structure of system dynamics, which also called as state- determined system, as follows (1) see formula 1 in the supplementary files section.

, where is a vector, which belongs to stocks or state variables, is a non-linear vector-valued function and is defined as set of parameters.

\subsection{Model Description}

\subsubsection{Causal Loop Diagrams (CLD)}

Causal Loop Diagram (CLD) is vital for observing system behavior, especially in closed loops, considering feedbacks which forms a basis for a system dynamics mentality. Also, CLD indicates the mapping of causeeffect relationships between variables. (Sterman, 2010). A loop of feedback includes two or more causalities between related variables. In the relationship between two or more variables, negative or positive relationship may be possible. The positive relationship between two variables indicates that they are proportionally affected which means one related variable increases when the other one increases. As an example, if there exists an arrow positively (+) signed at the end, starting from $A$ and coming to $B$, it indicates that if $A$ increases, $B$ also increases. Inversely, if there is a negative relationship between two variables having causeeffect relationship, an increase in A causes a decrease in B assigned as a negative (-) sign at the end (Bala et al., 2016).

For increasing amount of rare earth elements, different factors are taken into consideration to observe the behavior of the system. Since the relative factors of Causal loop differently affect the ratio of reusing and recycling ratios of rare earth elements in smartphones' touch screens, the total effect can be mainly positive only if technology development in waste collection centers, governmental and municipal incentives are applied in the Causal loop diagram.

\subsubsection{System Dynamics Modelling and Simulation of Rare Earth Elements in Smartphones}

The system dynamics modelling for rare earth elements in smartphones' touch screens has been designed in three main aspects. All inputs can be seen in table 1. The inputs have been simulated in kilogram(kg) and 
milligram(mg) as some information is found in different measure forms. The average mobile phone weigh is taken as 140 gram (URL3) and it is accepted that 350000 smartphones are thrown away in a day, which is equal to 152 million devices thrown away yearly. The inputs indicated in table 1 are applied in Anylogic simulation software by system dynamics approach given in Figure 4 as a closed loop supply chain. The maximum collection rate is accepted as $25 \%$ as given in URL 1 and the rest, $75 \%$ of smartphones, is thrown away without any collection, reusing or recycling process. As a classical closed supply chain, raw materials have been also fed with reused and recycled rare earth elements in the simulation. The main parts in the simulations are respectively governmental and municipal collection centres operated by government and municipalities.

Table 1. Description of system dynamics modelling parts and input names in simulation 


\begin{tabular}{|c|c|}
\hline Input Name in the model & Description \\
\hline MunicipallncentiveEffect & $\begin{array}{l}\text { Incentive(rate) given by municipalities for increasing } \\
\text { collection of smartphones }\end{array}$ \\
\hline GovernmentallncentiveEffect & $\begin{array}{l}\text { Incentive given by government for increasing collection } \\
\text { of smartphones }\end{array}$ \\
\hline $\begin{array}{l}\text { Indium,Lanthanum,Gold,Silver,Terbium,Yttrium } \\
\text { and Palladium }\end{array}$ & $\begin{array}{l}\text { Amount (mg) of each rare earth elements existing in } \\
\text { smartphones in the stocks after disassembly and } \\
\text { collection }\end{array}$ \\
\hline Refurbishment & $\begin{array}{l}\text { Refurbishment process for disassembly and reuse of } \\
\text { smartphones }\end{array}$ \\
\hline IncinerationandGarbage & $\begin{array}{l}\text { Amount of rare earth elements in smartphones' touch } \\
\text { screens for not being reused or recycled but going } \\
\text { through for incineration and garbage stocks }\end{array}$ \\
\hline TouchScreens & $\begin{array}{l}\text { Weight (gr) of touchscreen in smartphones taken } \\
\text { according to the weight distribution given in Table } 2 \text {. }\end{array}$ \\
\hline ReuseorResale & $\begin{array}{l}\text { Number of Smartphones not going through recycling } \\
\text { process }\end{array}$ \\
\hline Export & Number of Smartphones to export without recycling \\
\hline GovernmentalCollectionCenter & $\begin{array}{l}\text { Number of Smartphones being collected in } \\
\text { Governmental Collection Center. }\end{array}$ \\
\hline WasteCollectionCenter1 & $\begin{array}{l}\text { Rare earth elements' amount (mg) after recycling } \\
\text { process }\end{array}$ \\
\hline RawMaterial & $\begin{array}{l}\text { Raw Material Stock in order to reuse recycled } \\
\text { components and elements of smartphones and } \\
\text { manufacture new smartphones }\end{array}$ \\
\hline MunicipalCollectionCenter & $\begin{array}{l}\text { Number of Smartphones being collected in Municipal } \\
\text { Collection Center. }\end{array}$ \\
\hline DisposalStock & $\begin{array}{l}\text { Stock of not reused or recycled rare earth elements } \\
\text { after recycling process }\end{array}$ \\
\hline $\begin{array}{l}\text { Battery,AerialofPhones,Microphone, } \\
\text { BatteryConnectors,TouchScreens }\end{array}$ & $\begin{array}{l}\text { Weight of each part in stocks before the process of } \\
\text { going through waste collection center }\end{array}$ \\
\hline ThrowAway & Number of mobile phone waste without recycling \\
\hline
\end{tabular}

On the other hand, a smart contains 7 main parts and the distribution of weights in the simulation model changes based on Table 2. (Singh et al.,2018). Table 2 shows the weight distribution of the mobile phone components for a classical smartphone. The weights in the model are distributed and assigned as given in Table 2.

Table 2. Component distributions of smartphones based on their weights (Singh et al.,2018) 


\begin{tabular}{|ll|}
\hline Mobile phone components & Weight distribution (\%) \\
\hline Speakers & 2 \\
\hline Screws & 5 \\
\hline Aerial of phones & 10 \\
\hline Battery connectors & 35 \\
\hline Circuit boards & 15 \\
\hline LCD screens & 30 \\
\hline Microphones & 3 \\
\hline
\end{tabular}

Furthermore, as seen in Table 2, touch screens or LCD screens of smartphones have $30 \%$ of total weight. Given that a total weight of a smartphone is approximately equal to $140 \mathrm{~g}$., touch screen is nearly $42 \mathrm{~g}$. Also, these LCD screens include very crucial and rare earth elements, which becomes a scarce source. Table 3 shows some important rare earth elements weights found in smartphones touch screens which requires to be functional and operative.

Table 3. Important Rare Earth Elements' weight in smartphones (Singh et al., 2018 \& Jowitt et al., 2018 \& Weng et al., 2013, Silviera et al., 2015)

\begin{tabular}{|ll|}
\hline $\begin{array}{l}\text { Rare earth elements in smartphones touch } \\
\text { screens }\end{array}$ & $\begin{array}{l}\text { Weight }(\mathrm{mg}) \text { of rare earth elements in smartphones per } \\
1 \mathrm{~kg}\end{array}$ \\
\hline Silver & 1732.9 \\
\hline Gold & 190.9 \\
\hline Palladium & 40.16 \\
\hline Indium & 636 \\
\hline Terbium & 1.58 \\
\hline Yttrium & 1.39 \\
\hline Lanthanum & 1.61 \\
\hline
\end{tabular}

According to the table 2 and table 3 , the weights and distributions are proportionally taken place in the system dynamics modelling operated by Anylogic and these elements are accepted to be collected in Waste Collection Center except thrown away rare earth elements coming from not-recycled or not reused cell phones. Additionally, only $1 \%$ of rare earth elements are recycled in recycling process (Jowitt et al., 2018) and in the model, the scenarios are differently evaluated. In the modelling; first scenario is $1 \%$ of recycling of rare earth elements without any incentives, which is the current scenario in the current waste recycling process. For the next scenario, it is $4 \%$ of recycling of rare earth elements in smartphones touch screens with an effective and efficient supply chain management and incentives, which is future state and put in incentive sections as scalar for designed model simulation. Moreover, the part of collection centers, refurbishment and 
reuse or resale, e-waste recycling and export of supply chain are the general parts of smartphones' waste management as seen in the Figure 4 (Jang and Kim, 2010).

\section{Results And Discussions}

In the model, the recycled rare earth elements are directly sent through the raw material and production process. Figure 5 shows the current state of recycling of rare elements' weights $(\mathrm{mg})$ in smartphones' touch screens after 45 years without any incentives and at a very low rare (1\%) recycling operation.

In the model, there exist two incentives, which are governmental collection incentives supporting governmental collection point for increasing the collection and municipal collection incentives for public awareness. Governmental incentive and municipal incentive taken into consideration (Ylä-Mella et al., 2015) are respectively put in the model at a rate of $10 \%$ and $5 \%$.

Figure 6 shows the future state of recycling of rare elements' weights $(\mathrm{mg})$ in smartphones' touch screens after 45 years with incentives and at a rate of $(3 \%)$ recycling operation with two separate collection points.

By the aid of incentives and effective collection points, which are governmental collection points and municipal collection points, the recycled rare earth elements in smartphones' touch screens can increase up to $4.13 \%$ of total wastes by stating that only $1 \%$ of rare earth elements is recycled and reused actually.

\section{Conclusion}

Increasing use of smartphones parallelly increase mobile phone waste. Taking into consideration the fact that mobile phone reuse and recycling rate is only $25 \%$, this rate threaten environmental, social and economic sustainability. Moreover, rare earth elements found in almost every part of smartphones are considered as recyclable waste and the majority of these can be reused in production process. However, due to insufficient waste management and effective policy deficiencies, rare earth elements in smartphones' screens are recycled at a rate of only $1 \%$ and the rest is thrown away or incinerated. In the proposed system dynamics model for these elements, which face to an increasing risk of extinction, 7 rare earth elements, which are gold, palladium, lanthanum, silver, terbium, yttrium and indium, have been evaluated and an effective closed loop supply chain management has been proposed for these elements in touch screens of smartphones, along with an effective mobile phone waste management. The proposed closed loop supply chain model has been designed with system dynamics. By the aid of incentives and different collection points, these elements can be recycled up to $4.13 \%$ with the proposed model while only $1 \%$ of these elements are actually recycled. In future studies, different policies can be examined for all countries in the world and a separate model can be designed for each country based on its policies. On the other hand, since the waste management policy of each country is different, the current situation of these policies and the future situation can be discussed according to the developments. Also, for further researches, if data is available, other rare earth elements can be evaluated by a system dynamics approach.

\section{Declarations}




\section{Authors' contributions}

Both of authors (Aziz Kemal Konyalıoğlu and Illke Bereketli) have been equally included in the research and worked equally.

Aziz Kemal Konyalığlu and Ilke Bereketli should be respectively AKK and IB.

Funding There is no funding for this research.

Data availability Research data can be obtained from the corresponding author through email.

\section{Compliance with ethical standards}

Ethical approval We certify that the manuscript titled. "Rare earth elements' waste management for smartphones' touch screens by system dynamics modelling" (hereinafter referred to as "the Paper") has been entirely our original work except otherwise indicated, and it does not infringe the copyright of any third party. The submission of the Paper to Environmental Science and Pollution Research implies that the paper has not been published previously (except in the form of an abstract or as a part of a published lecture or academic thesis), that it is not under consideration for publication elsewhere, that its publication is approved by all authors and that, if accepted, will not be published elsewhere in the same form, in English or any other language, without the written consent of the Publisher.

Copyrights for articles published in Environmental Science and Pollution Research are retained by the author(s), with first publication rights granted to Environmental Science and Pollution Research.

Consent to participate - We affirm that all authors have participated in the research work and are fully aware of ethical responsibilities.

Consent to publish-We affirm that all authors have agreed for submission of the paper to ESPR and are fully aware of ethical responsibilities.

Competing Interests- The authors declare that they have no conflict of interest.

\section{References}

Ardi, R., \& Leisten, R. (2016). Assessing the role of informal sector in WEEE management systems: A System Dynamics approach. Waste management, 57, 3-16. https://doi.org/10.1016/j.wasman.2015.11.038

Bala B.K., Arshad F.M., Noh K.M. (2017) Causal Loop Diagrams. In: System Dynamics. Springer Texts in Business and Economics. Springer, Singapore. https://doi.org/10.1007/978-981-10-2045-2_3

Cai, Y., Yue, W., Xu, L., Yang, Z., \& Rong, Q. (2016). Sustainable urban water resources management considering life-cycle environmental impacts of water utilization under uncertainty. Resources, Conservation and Recycling, 108, 21-40. https://doi.org/10.1016/j.resconrec.2016.01.008 
Ciplak, N., \& Barton, J. R. (2012). A system dynamics approach for healthcare waste management: a case study in Istanbul Metropolitan City, Turkey. Waste Management \& Research, 30(6), 576-586.

https://doi.org/10.1177/0734242X12443405

Dace, E., Bazbauers, G., Berzina, A., \& Davidsen, P. I. (2014). System dynamics model for analyzing effects of eco-design policy on packaging waste management system. Resources, Conservation and Recycling, 87, 175-190. https://doi.org/10.1016/j.resconrec.2014.04.004

Dhanshyam, M., \& Srivastava, S. K. (2021). Effective policy mix for plastic waste mitigation in India using System Dynamics. Resources, Conservation and Recycling, 168, 105455.

https://doi.org/10.1016/j.resconrec.2021.105455

Forrester, J. W. (1994), System dynamics, systems thinking, and soft OR. Syst. Dyn. Rev., 10: 245 doi:10.1002/sdr.4260100211

Forrester J.W. (1961), Industrial Dynamics, The MIT Press, Cambridge, Massachusetts.

Forrester, J. W. (1993). System dynamics and the lessons of 35 years. In A systems-based approach to policymaking (pp. 199-240). Springer, Boston, MA

Geyer, R., \& Blass, V. D. (2010). The economics of cell phone reuse and recycling. The International Journal of Advanced Manufacturing Technology, 47(5-8), 515-525.

Gu, F., Summers, P. A., \& Hall, P. (2019). Recovering materials from waste smartphones: Recent technological developments. Journal of Cleaner Production, 237, 117657. https://doi.org/10.1016/j.jclepro.2019.117657

Hao, J. L., Hill, M. J., \& Shen, L. Y. (2008). Managing construction waste on-site through system dynamics modelling: the case of Hong Kong. Engineering, Construction and Architectural Management. https://doi.org/10.1108/09699980810852646

He, P., Feng, H., Hu, G., Hewage, K., Achari, G., Wang, C., \& Sadiq, R. (2020). Life cycle cost analysis for recycling high-tech minerals from waste smartphones in China. Journal of Cleaner Production, 251, 119498.

Huang, E. M., Yatani, K., Truong, K. N., Kientz, J. A., \& Patel, S. N. (2009). Understanding mobile phone situated sustainability: the influence of local constraints and practices on transferability. IEEE Pervasive Computing, (1), 46-53.

Inghels, D., \& Dullaert, W. (2011). An analysis of household waste management policy using system dynamics modelling. Waste management \& research, 29(4), 351-370.

https://doi.org/10.1177/0734242X10373800

Jang, Y. C., \& Kim, M. (2010). Management of used \& end-of-life smartphones in Korea: a review. Resources, Conservation and recycling, 55(1), 11-19.

Jha, M. K., Kumari, A., Jha, A. K., Kumar, V., Hait, J., \& Pandey, B. D. (2013). Recovery of lithium and cobalt from waste lithium ion batteries of mobile phone. Waste management, 33(9), 1890-1897. 
Jowitt, S. M., Werner, T. T., Weng, Z., \& Mudd, G. M. (2018). Recycling of the rare earth elements. Current Opinion in Green and Sustainable Chemistry, 13, 1-7.

Lee, C. K. M., Ng, K. K. H., Kwong, C. K., \& Tay, S. T. (2019). A system dynamics model for evaluating food waste management in Hong Kong, China. Journal of Material Cycles and Waste Management, 21(3), 433456. https://doi.org/10.1007/s10163-018-0804-8

Liu, J., Liu, Y., \& Wang, X. (2020). An environmental assessment model of construction and demolition waste based on system dynamics: a case study in Guangzhou. Environmental Science and Pollution Research, 27(30), 37237-37259.

Lu D, Iqbal A, Zan F, Liu X, Chen G. Life-Cycle-Based Greenhouse Gas, Energy, and Economic Analysis of Municipal Solid Waste Management Using System Dynamics Model. Sustainability. 2021; 13(4):1641. https://doi.org/10.3390/su13041641

Nnorom, I. C., Ohakwe, J., \& Osibanjo, O. (2009). Survey of willingness of residents to participate in electronic waste recycling in Nigeria-A case study of mobile phone recycling. Journal of cleaner production, 17(18), 1629-1637.

Ongondo, F. O., \& Williams, I. D. (2011). Mobile phone collection, reuse and recycling in the UK. Waste management, 31(6), 1307-1315.

Phonphoton, N., \& Pharino, C. (2019). A system dynamics modeling to evaluate flooding impacts on municipal solid waste management services. Waste Management, 87, 525-536.

https://doi.org/10.1016/j.wasman.2019.02.036

Pinha, A. C. H., \& Sagawa, J. K. (2020). A system dynamics modelling approach for municipal solid waste management and financial analysis. Journal of Cleaner Production, 269, 122350, https://doi.org/10.1016/j.jclepro.2020.122350

Polák, M., \& Drápalová, L. (2012). Estimation of end of life smartphones generation: the case study of the Czech Republic. Waste management, 32(8), 1583-1591.

Richardson, G. P. (2020). Core of System Dynamics. System Dynamics: Theory and Applications, 11-20.

URL1: Kennedy, M. (2013). Cell Phone Recycling

https://www.wastecare.com/Articles/Cell_Phone_Recycling.htm. Accessed 19 February 2021

URL2: Compound Interest (2014) Elements of a Smartphone, https://i1.wp.com/www.compoundchem.com/wp-content/uploads/2014/02/The-Chemical-Elements-of-aSmartphone-v2.png?ssl=1 . (Accessed 19 February 2021)

URL3: (2018) Weekly poll results: the ideal weight for a phone is between $140 \mathrm{~g}$ and $170 \mathrm{~g}$, https://www.gsmarena.com/weekly_poll_results_the_ideal_weight_for_a_phone_is_between_140g_and_170gnews-29934.php. (Accessed 19 February 2021) 
URL4: https://earth911.com/eco-tech/20-e-waste-facts/ (Retrieved on 7th of May, 2020)

Sarath, P., Bonda, S., Mohanty, S., \& Nayak, S. K. (2015). Mobile phone waste management and recycling: Views and trends. Waste management, 46, 536-545.

Silveira, A. V. M., Fuchs, M. S., Pinheiro, D. K., Tanabe, E. H., \& Bertuol, D. A. (2015). Recovery of indium from LCD screens of discarded cell phones. Waste Management, 45, 334-342.

https://doi.org/10.1016/j.wasman.2015.04.007

Singh, N., Duan, H., Yin, F., Song, Q., \& Li, J. (2018). Characterizing the materials composition and recovery potential from waste smartphones: A comparative evaluation of cellular and smartphones. ACS Sustainable Chemistry \& Engineering, 6(10), 13016-13024.

Sinha, R., Laurenti, R., Singh, J., Malmström, M. E., \& Frostell, B. (2016). Identifying ways of closing the metal flow loop in the global mobile phone product system: A system dynamics modeling approach. Resources, Conservation and Recycling, 113, 65-76.

Soo, V. K., \& Doolan, M. (2014). Recycling mobile phone impact on life cycle assessment. Procedia cirp, 15, 263-271.

Sterman, J. (2010). Business dynamics. Irwin/McGraw-Hill c2000...

Sukholthaman, P., \& Sharp, A. (2016). A system dynamics model to evaluate effects of source separation of municipal solid waste management: A case of Bangkok, Thailand. Waste Management, 52, 50-61. https://doi.org/10.1016/j.wasman.2016.03.026

Thavalingam, V., \& Karunasena, G. (2016). Mobile phone waste management in developing countries: A case of Sri Lanka. Resources, Conservation and Recycling, 109, 34-43.

Weng, Z. H., Jowitt, S. M., Mudd, G. M., \& Haque, N. (2013). Assessing rare earth element mineral deposit types and links to environmental impacts. Applied Earth Science, 122(2), 83-96.

Xu, C., Zhang, W., He, W., Li, G., \& Huang, J. (2016). The situation of waste mobile phone management in developed countries and development status in China. Waste management, 58, 341-347.

Yao, L., Liu, T., Chen, X., Mahdi, M., \& Ni, J. (2018). An integrated method of life-cycle assessment and system dynamics for waste mobile phone management and recycling in China. Journal of cleaner production, 187, 852-862.

Yin, J., Gao, Y., \& Xu, H. (2014). Survey and analysis of consumers' behaviour of waste mobile phone recycling in China. Journal of Cleaner Production, 65, 517-525. https://doi.org/10.1016/j.jclepro.2013.10.006

Ylä-Mella, J., Keiski, R. L., \& Pongrácz, E. (2015). Electronic waste recovery in Finland: Consumers' perceptions towards recycling and re-use of smartphones. Waste management, 45, 374-384. 
Figures

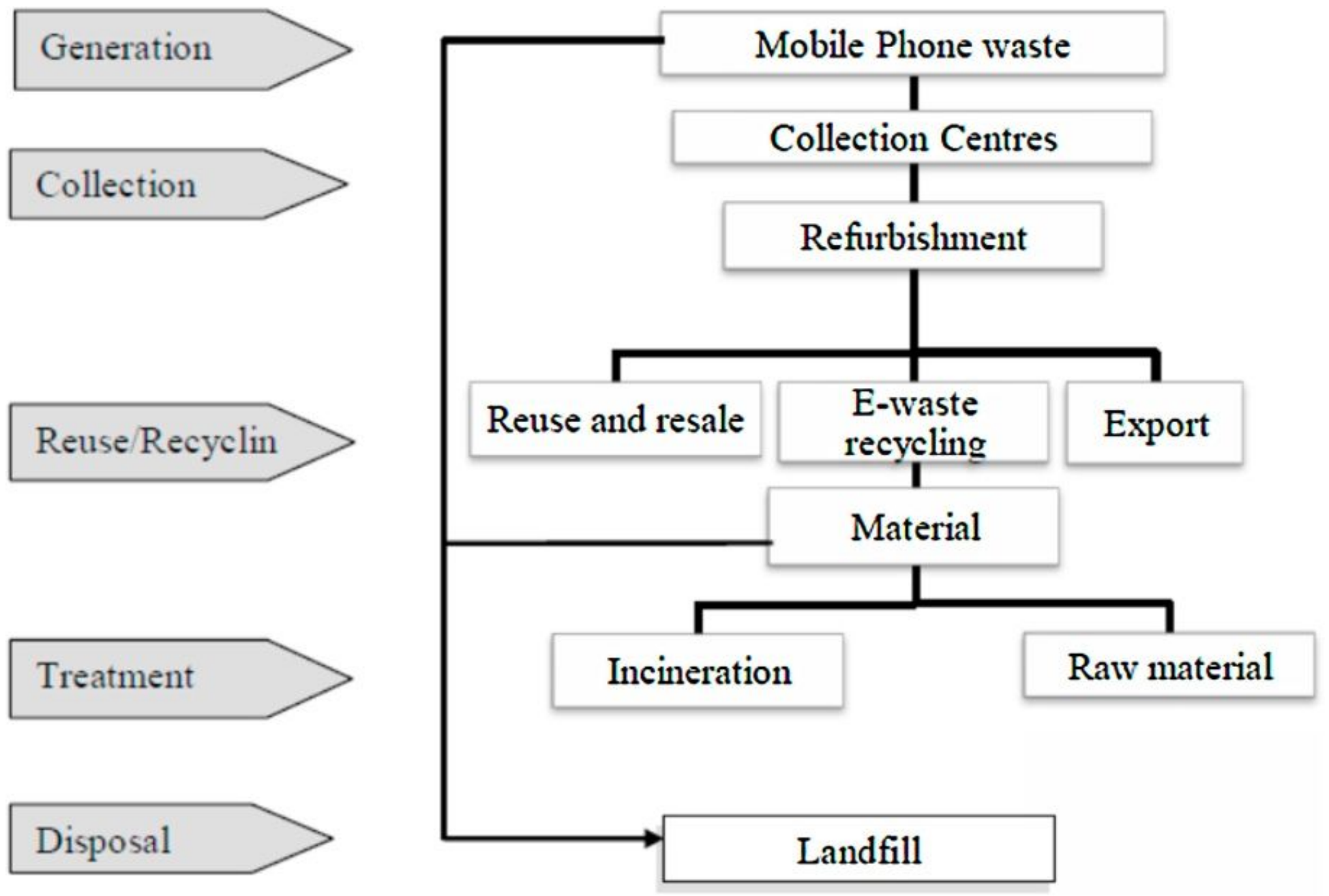

Figure 1

Classic illustration of smartphones' waste management (Jang and Kim, 2010)

\begin{tabular}{|c|l|}
\hline $\begin{array}{c}\text { 1) Start defining the problem } \\
\text { dynamically }\end{array}$ & $\begin{array}{l}\text { - Indentifying actions and changes } \\
\text { - Using graphs and time series }\end{array}$ \\
\hline \begin{tabular}{|l|l|} 
2)Identifying all concepts in \\
real system
\end{tabular} & $\begin{array}{l}\text { - Feedbacks and Causalities } \\
\text { - Inward and outward structures }\end{array}$ \\
\hline $\begin{array}{l}\text { 3)Defining the key variables } \\
\text { and connections in the system }\end{array}$ & $\begin{array}{l}\text { - Understanding representations } \\
\text { - Deterministic or stochastic variables }\end{array}$ \\
\hline
\end{tabular}

Figure 2

System Dynamics methodology (Richardson,2020) 


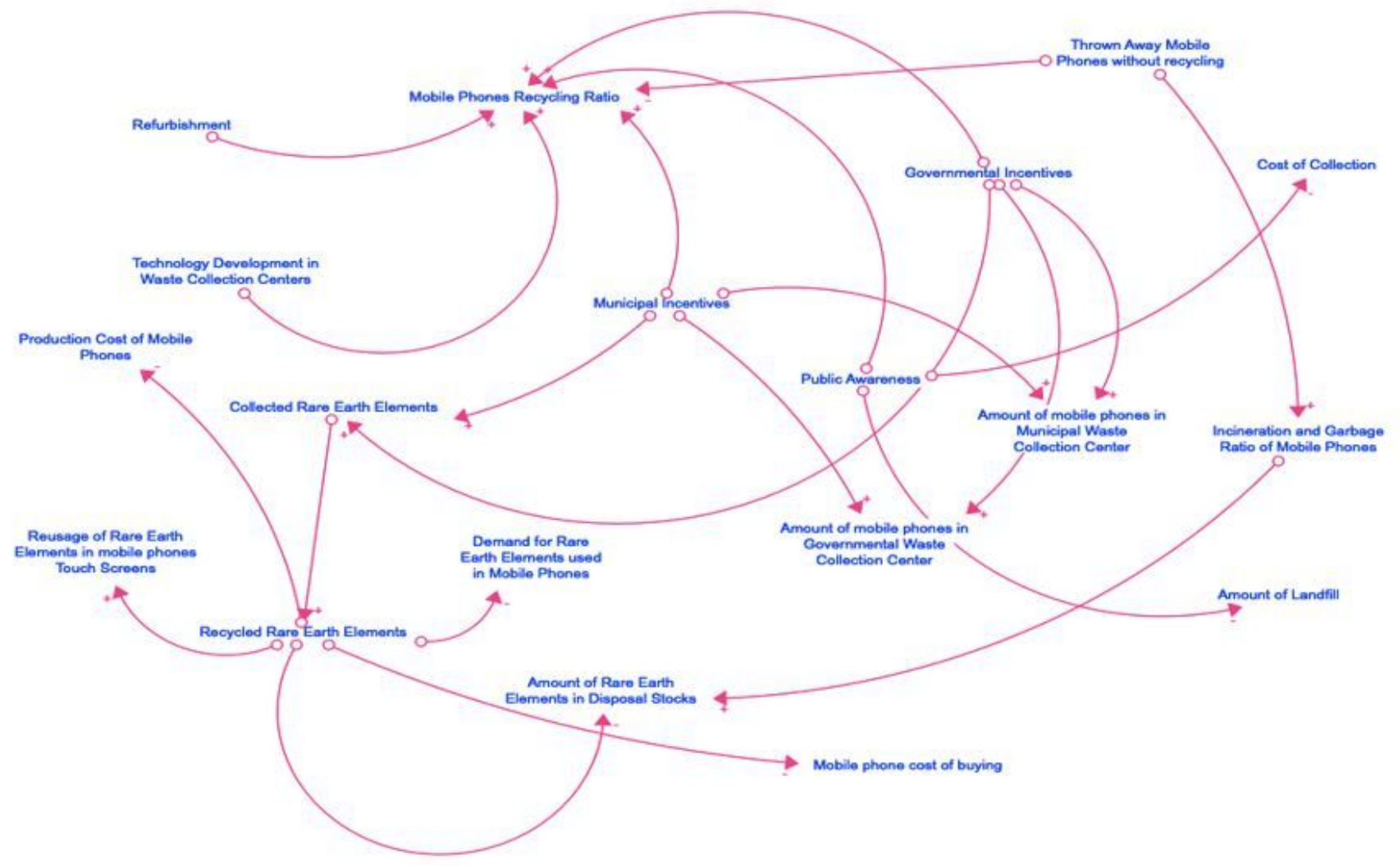

Figure 3

The Causal loop and affecting factors of reusing and recycling ratios of rare earth element in smartphones 




\section{Figure 4}

System dynamics modelling in Anylogic software for waste management of rare earth elements in smartphones' touch screens 


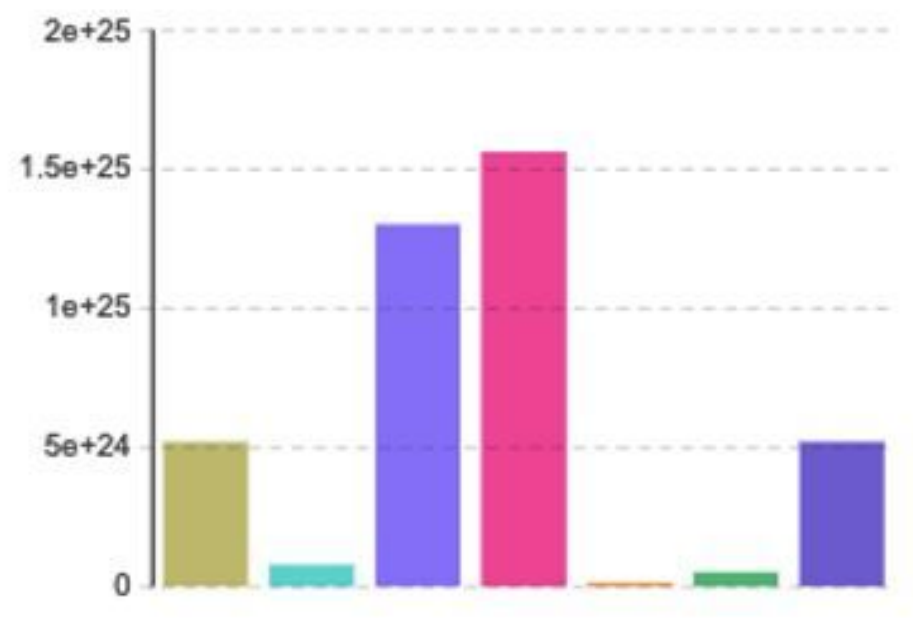
Gold Amount(mg) $5.21 \mathrm{e}+24$
Palladium Amount(mg) $7.82 \mathrm{e}+23$
Lanthanum Amount(mg) $1.3 \mathrm{e}+25$
Silver Amount(mg) $1.56 \mathrm{e}+25$
Terbium Amount(mg) $1.3 \mathrm{e}+23$
Yttrium Amount(mg) $5.21 \mathrm{e}+23$
Indium Amount(mg) $5.21 \mathrm{e}+24$

\section{Figure 5}

The current state of rare elements' weights $(\mathrm{mg})$ in smartphones touch screens 


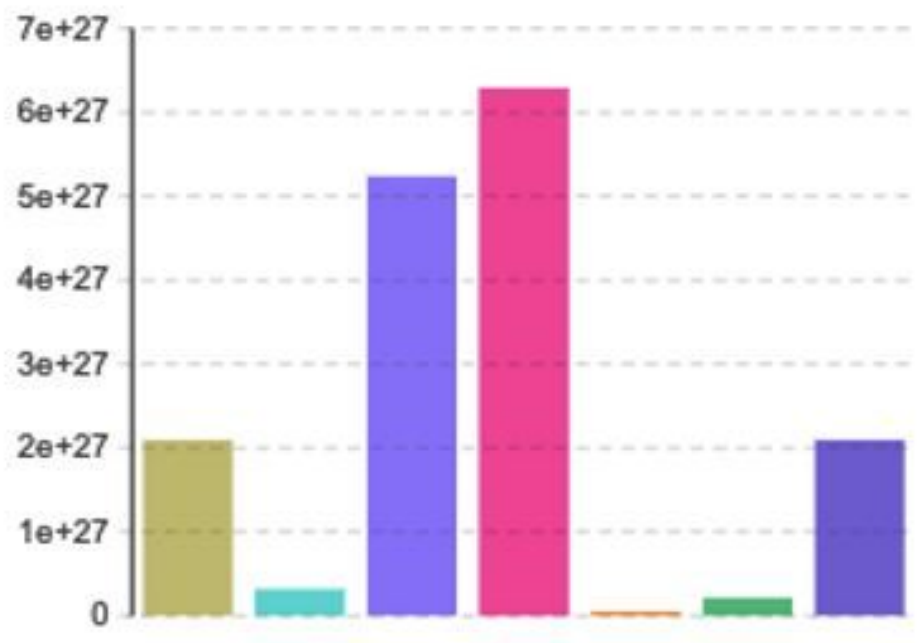

Figure 6

The future state of rare elements in smartphones touch screens

\section{Supplementary Files}

This is a list of supplementary files associated with this preprint. Click to download.

- formula.docx 